\title{
Reopening libraries in COVID 19 pandemic: challenges and recommendations
}

\author{
Deelip D. Mestri
}

Librarian, International Institute for Population Sciences (Deemed University), Govandi Station Road, Deonar, Mumbai, Maharashtra, India

*Corresponding Author: Deelip D. Mestri

Email: lio@iips.net

\begin{abstract}
The COVID 19 has forced to 150 countries to close the school libraries, according to UNECSO 84 countries have closed their public libraries and 98 countries have closed their national libraries. The college and the university libraries are also compelled to close libraries. India has ranking second largest county in term of population in the World after China. As a precautionary measure, The Union Government of India has declared the national level closed down after $22^{\text {nd }}$ March, 2020 to break the chain of the COVID 19 pandemic. But the day is not far away to start the process of removing the restrictions step by step in phased manner. Hence, we the library professionals should also be prepare to reopen the libraries along with the COVID 19. We have a huge responsibility to protect the clienteles, staff and the library resources in such a pandemic situation. While reopening the library after the lock down we need to take precautionary measures to slow down and prevent the COVID 19. The author has mentioned the challenges and suggested recommendations of the libraries during post lock down period. The author has also suggesting to revise the library rules based on the recommendations and the level of the intensity of the pandemic.
\end{abstract}

Keywords: Reopening library, Library in COVID 19, COVID 19.

\section{Introduction}

The COVID 19 is now called Severe Acute Respiratory Syndrome Corona Virus 2 (SARS-CoV-2) old name was called HCoV-19, emerged in China, in late 2019 and is now causing a pandemic (Van Dormalen, Neelatji et al. 2020) and covered widest area of the World. Coronavirus refers to a family of viruses. COVID-19 - or Coronavirus Disease - is the infectious disease caused by a newly discovered type of coronavirus. COVID stands for CO for Corona, VI for Virus and D for Disease (WHO, 2020).

As the World Health Organization (WHO) has set out, most people infected with the COVID-19 virus will experience mild to moderate respiratory illness and recover without requiring special treatment. Older people, and those with underlying medical problems like cardiovascular disease, diabetes, chronic respiratory disease, and cancer are more likely to develop serious illness (UNICEF; 2020).

\section{Spread of COVID 19}

The COVID-19 virus spreads primarily through droplets of saliva or discharge from the nose when an infected person coughs or sneezes. The surface, wherever spreads the droplets through the coughs and sneezes remained as active area for transmission of the disease for the period of ranges between 24 hours to 72 hours, depend on type of surface. If that active area touched by any other person, the chances of transmission of COVID 19 to the touched one increases and in this way the disease spreads in the society. It has recommended to control the situation is be well informed about the COVID-19 virus, the disease it causes and the process of spreads. Once the people came to know the process of creation and transmission of COVID 19 it may be helpful to slowdown and prevention of the disease (UNICEF, 2020).

COVID 19 is not new virus, but this type of harmful virus never damaged the human life in the past as it has started at the late 2019. When it has started, the entire World economy and the social life has stopped including publishing industry. Hence, printed literature is not available on the above topic. But important agencies like, World Health Organisation (WHO), UNICEF, Ministry of Health of some countries have posted the general guidelines to slow down and prevention of the pandemic. International Federation of Library Association (IFLA), American Library Association (ALA), and some LIS associations have uploaded the precautionary measures on the reopening the libraries to control the pandemic from library. The general guidelines of the pandemic as well as library specific literature has referred from the above noted sources to complete this study and prepared exclusively for re-opening the closed libraries.

\section{Precautionary measures to prevent from COVID 19}

Self-quarantine is the best way to avoid the COVID 19, but human being is social animal, the pandemic has no vaccine and the isolation for longer duration is not possible to any person. In the light of the above, it has recommends that people should follow respiratory etiquette (for example, by coughing and sneezing into a flexed elbow, or a tissue that they immediately throw away). They should also wash their hands or use to apply an alcohol-based sanitizer to hands frequently. They should not touch their faces and social distancing should be always keep in mind. Further, this is also to be noted that the hotspots of COVID-19 should be avoided, especially if you, or those you live with, are aged or otherwise vulnerable people (for example, you or they have diabetes, heart or lung disease and cancer patients).

The COVID 19 symptoms have observed fever, tiredness and a dry cough. In addition to the above, trouble to breath, aches and pains, sore throat, and some people will report diarrhoea, nausea and runny nose, who are otherwise healthy should self-quarantine and contact the medical practitioner or call a COVID-19 helpline number for advice on testing and referral (WHO, 2020). 


\section{Situation of libraries at world level}

Libraries in the World are facing hard problem of providing library services ranging from continuing existing services or some of them or full closure. It is difficult to match the library services with the government decisions and intensity of the pandemic in different part of the area. We are aware that governments themselves are taking different approaches, sometimes ordering the closure of all institutions, others indicating that life should continue as usual, and others simply leaving decisions up to library directors. According to the source, in 150 countries in the World have closed the school libraries, in many countries similar situation can be seen about university libraries. As per the global scenario, 84 countries from all the continents in the world have closed their public libraries, 98 countries have closed their national libraries (UNESCO, 2020). In the meanwhile, libraries in Australia (Oceania), Austria (Europe), Belgium (Europe), Bulgaria (Europe), Canada (North America), Croatia (Europe), the Czech Republic (Europe), Denmark (Europe), Estonia (Europe), Finland, (Europe), France (Europe), Germany (Europe), Hong Kong (China), Italy (Europe), Japan (Asia), Macao (China), the Netherlands (Europe), New Zealand (Oceania), Norway (Europe), Poland (Europe), Sint Maarten (North America), Slovakia (Europe), Slovenia (Europe), Spain (Europe), Svalbard (Europe) and Switzerland (Europe) prepared to re-open with taking into considerations of the health of staff, clientele and other library resources. Over $90 \%$ of municipalities have keep libraries open in Sweden (Europe) and over $85 \%$ of municipalities have extended the services (IFLA, 2020).

India has divided into 28 states and nine Union Territories (UTs) and every State and UT has different stage of COVID 19. The Union Government has put criteria like active cases, doubling rate, and the deaths due to the pandemic. The author has taken the active COVID 19 cases of every State and UT as on $7^{\text {th }}$ June 2020 (MOHFW) and grouped them according to the ranges of the cases. There are 1,20,406 active cases of COVID 19 in India. The distribution of the active cases and the groups of States and the UTs have as given below:

Maharashtra, Delhi and Tamil Nadu are observed on top for active COVID 19 cases as 42609, 16229 and 13506 respectively. Gujarat, West Bengal and Uttar Pradesh have between the ranges of 5057 to 3828 active cases. Karnataka, Madhya Pradesh, Rajasthan, Jammu \& Kashmir and Bihar have found the active cases between the ranges of 3186 to 2254. Haryana, Telangana, Andhra Pradesh, Assam, Odisha, and Kerala have found the active cases between the ranges of 1794 to 1030. Uttarakhand, Tripura, Chandigarh, Jharkhand, Punjab, Goa, Himachal Pradesh, Nagaland and Manipur have the active cases between the ranges of 869 to 105 . Puducherry, Ladhak, Arunachal Pradesh, Chandigarh, Mizoram, Meghalaya, Dadar \& Nagar Havil, have found the active cases between the ranges of 63 to 18 . Sikkim has 7 active cases and 8605 active cases have been reassigned to the various states. It has observed that the UTs of Andaman \& Nicobar and Lakshadweep have controlled the COVID 19 situation and as on $7^{\text {th }}$ June, 2020 no single active case has recorded. But this situation is not permanent, the movement of people have started in the country and the situation may change at any time. Even some States and UTs may change its ranges from higher to middle or even lower or vis-à-vis.

\section{Promoting hygiene}

Be sure that the library staff must have a habit of (regular) wash their hands frequently (at least before and after coming into contact with suspicious material), access to safety materials such as gloves and facemasks, and that hands sanitizer is available at the entrance of the library as well as next to equipment such as computers, electronic on/off switches, land line telephone in the library (if common). The provision of (Pedal) bins for waste tissue papers or other potentially contaminated material have suggested (Flemish guidance, 2020) for the library. The frequently cleaning of library at least twice/thrice or as required has suggested to avoid unwanted pandemic situation in the library. It may be necessary to employ more cleaning staff, or to extend working hours. They can be supported in identifying the surfaces at most risk, and give the attention wherever necessary.

The temperature check unit/s (thermometer) at the entrance is an essential and suitable staff to check the temperature is required during library working hours. In academic libraries in Hong Kong, the library users are subject to temperature checks and the facemasks is essential (IFLA, 2020).

The toilets in the library are the common area for spread of COVID 19. It has suggested closing the toilets in the library (Czech Republic Libraries) and restricting their use. Better to prepare intensifying cleaning schedules and take the interval (closing the library) as a whole for short periods during the working day in order to clean (as in Macao, China, Slovakia, or at the National University Library of Croatia), the surfaces which are regularly touched.

\section{Preparation for re-opening}

In many libraries in the World, there are steps have taken towards lifting restrictions, put at the time of closedown, not all but at least partially. The working hours and working days remain uncertain, in such a way that safety should be a top priority. In such situation, libraries:

\section{Formulate library policy}

1. Post lockdown period will be completely different environment than it was before lockdown. The library rules and regulations, guides, brochures, study room facilities, outside visitors, guests, the staff and student relatives, there will be restrictions to everyone. There will be required to change the library policy, rules and regulations, to make sure that every person and the resources should be safe in the library.

2. Putting limit on numbers of students, staff and visitors using the library at any one time, and see that how to enforce these, as well as identifying locations in and around the library where people may gather closely 
together, for example using one-way (if possible) entrance and exit separate. Limiting furniture, closing the reading rooms, or continuing to postpone programs. It is also advisable to close the toilets for safety purpose (practically it is not easy), the alternative is intensive cleaning the toilets frequently.

3. Promoting online services and resources in order to control on numbers looking to visit the library

4. Developing the system of overall collection development of e-books and provide access through remote without human contact

5. The library rules should be revised and it should be clearly communicated to all via e-mail and the notice board. If any changes takes place in the rule (revised) that should also be communicated at an earliest to the students and staff and all the library members.

6. The library system is in transition phase at least up to the end of COVID 19. To protect the staff from the virus, the necessary equipment should be provided and training is an essential factor. The equipment includes transparent screens if necessary, providing the furniture in such a way that minimum distance with the students and the library users should maintain. Promoting work from home whichever is possible in this way numbers of the staff, students and other users can be put under control.

7. Focusing on regular cleaning processes, short breaks should be provided for library exclusive for cleaning purpose. The attention should be given for intensifying cleaning to the plastic, metallic surface where the virus appear for longer period, except the surfaces of copper and hard paper where the virus appear for short period.

8. It is needed to clarify that if situation of spreading COVID 19 founds rapidly due to the opening the library, it may close at any time for the safety of all with or without notification and it will be reopen after the situation come normal and safe or at least under control.

India is geographically vast country with 28 States, nine UTs and further 739 districts. The climate from south India to North India is extremely differ and similarly it also differ from east and west part of the country. Accordingly, the intensity of the diseases is not equal at country level as well as state and UT or even district level. According to the intensity of the disease the library re-opening strategies have suggested as below:

\section{Levels of re-opening of the library}

According to the stage of COVID 19, there may be four levels of re-opening the library in India. The appropriate level may be selected and apply to the library for the safety of clienteles, staff and other library resources.

1. More or less as usual (States / UTs where $<99$ active cases found)

2. Few restrictions (States / UTs where $>100$ and $<999$ active cases found)

3. Minimum service (States / UTs where $>1000$ and $<5000$ active cases found)
4. Complete close (Sates / UTs where $>5000$ active cases have found)

(The above levels or categories are not based on any medical background or support but the author has categorised to provide the library services with taking care of its resources including human resources and the asset, but the librarians and the authorities may consult the medical professionals for safety purpose, if felt necessary).

(i) More or less as usual: (States / UTs where No < 99 active cases found)

In some States and UTs the active cases have been limited as compared to other part of the country. The precautionary measures have to be taken to continue the situation without increasing further active cases of COVID 19. Such type of the libraries may:

1. Keeping always operation of thermometer and the suitable staff at the entrance to check the body temperature of people coming to the library

2. Made available soap and warm water to wash the hands frequently

3. The library must have availability of alcohol based hand sanitizer

4. Maintaining cleanliness particularly on plastic, metallic frequently including computers, laptops, toys etc.

5. The staff and users should be encouraged to take the homequarantine and medical treatment if required to recover if they are feeling ill, instead of coming to work

6. Upload pages with most useful links to authentic information sources for users on their URLs

7. Promote to maximum use of digital and online resources

(ii) Few restrictions: (States / UTs where > 100 and < 999 active cases found):

In this situation, libraries may: The serial number $1-3$ point no. (i) More or less as usual will be common to Sr. No. (ii).

1. The users of this type of library should be educated and informed frequently through webinars or workshops, especially for vulnerable groups. In addition to the above the efforts to ensure hygiene, disinfecting hard surfaces. Removing riskier items like toys or virtual reality headsets from library circulation.

2. Considering of closing study halls or rooms where students may spend a longer time in the company of each other's.

3. Preparing for further restrictions, such as, ensuring that the staff members have the skills and equipment to work remotely (if possible) and the services, as far as possible, can still be provided online.

(iii) Minimum service (States / UTs where > 1000 and < 5000 active cases found): In these situations, libraries may: The serial number $1-3$ of point no. (i) More or less as usual will be common to Sr. No. (iii).

1. Fully closing spaces and only continuing the possibility to issue or return books at a circulation counter, or via a book drop. Some countries are experimenting with home delivery and pick-up services of library books. Only prebooked students and visitors via e-mail are allowed for limited time. 
2. If Indian libraries adopted pre-booked method they should provide the mapping system of available seats (chairs) in the library to pre-book users.

3. Implementing quarantine procedure on returned books for the suitable (as per policy) period.

4. Implementing remote access to library resources as well as continuing the online education program of the library.

5. Finalising and testing measures for suitable library staff to work from home and allowing them to do so.

(iv) Complete close (Sates / UTs where > 5000 active cases have found): In this type of situations, the library should be closed but with the help of technology the services should be continue and the libraries may:

1. Ensuring that all staff working from home.

2. If the staff whoever has assigned to come into work, once or twice in a week, ensuring that they followed social distancing rule.

3. To keep continuing of communication with users regarding ongoing library services.

4. Organising online webinars to educate the library users and the society.

5. To avoid legal completions, to educate regarding copyright issues

6. Promoting use of online libraries services other tools.

7. Ensuring that the overall collection development should be diverted towards e-books and e-journals.

8. Offering remote access to e-books and e-journals and digital resources

9. Offering an amnesty on issued physical books to the borrowers.

10. Raising awareness of continuation of library services through the front pages of the Institute websites, and supplemented with putting up posters in the windows of library.

Our responsibilities are to protect the library users, staff and the library resources. The existing library rules should be revised according to the requirement of the library activities mentioned at different stages as (i) to (iv). The revised rule should be notified to all, for slowdown and control on spreading of COVID 19 through the library.

\section{Handling materials}

A key question the library material should not work as carrier of coronavirus. At this stage the only universal recommendations on maintaining social distance between two persons. But the libraries would not restrict only with the social distancing between person to person but it has to be extended between active library material to the persons.

The research has proved the survival of the corona virus, in the air and on different types of surfaces. It shows that it survives for longer duration surfaces like plastics and steel, and less longer on the surfaces like cardboard and copper, although these tests were performed in laboratory conditions and infection risk does fall over time (Van Dormalen, Neelatji et al. 2020).

According to the presentation in webinar of the Institute of Museum and Library Services in the (IMLS) USA, the risk of spreading the virus from the paper surface is lower than the hard surfaces, regularly touched to such hard surfaces posing high risk of spreading COVID 19. According to Dutch Government, the chance of catching the virus from paper surfaces, such as mail is low. The hard surfaces of metallic door handles, computer keyboards, computer / laptop mouse, CDs and DVDs and such other material would carry the virus, so should be needed regularly intensifying cleaned or removed from library circulation.

It is to be noted that, if issued book or other piece of equipment has been in close contact with the infected person, it may be appropriate way to keep a particular book or the equipment in isolation. The duration of remain active of the virus is depend on the type of surface and the ranging from minimum 24 hours to maximum 72 hours. (NEIJ \& French Government).

Let us see what practice has followed in some other countries for re-opening the libraries when the COVID 19 pandemic is active?

The uncertainty of the duration of COVID 19 that still not clear in the World. The IMLS of USA has set up REALM (Re-opening Archives, Libraries and Museums) with a partnership of OCLC, and the Battelle Institute and IFLA to explore the possibilities, how to ensure safe handling of the situation till the pandemic return to the normal. This will help to the libraries for the preparation to reopen the libraries with due consideration of the caring of the people in around and around the library as well as the library material.

As current situation only suggest the remedy to control the pandemic is quarantine or isolation. It is applicable not only to human being but the books and other library material too. Some libraries have insisted a waiting period (quarantine) before touching returned books, while some libraries have made it clear that no-one is required to return books and other reading materials until things return to normal. Some examples are, Public Health Department of England has suggested that the risk of spreading corona virus on the surface of cardboard can be considered negligible after the isolation period of 24 hours, and on the surface of plastic is negligible after 72 hours. The Danish libraries not in favour of quarantines of books after return. The libraries in Ireland have following the quarantine time of 72 hours wait, to the materials which have been returned to the library or last handled since the starting date of lock-down. The Australian Library Association has suggested that 24 hours of quarantine is enough for books and papers but for plastic covers, such as CD / DVDs, suggested cleaning with alcohol wipes. Some of the libraries from Duque do Caixas campus of Federal University of Rio de Janeiro and also the libraries in Egypt have using sunlight to disinfection the library materials. Whereas the Czech government has suggested two days quarantine is required to disinfect the corona virus. The Netherlands, Belgium and Switzerland have suggested 72 yours duration will the safety from all the aspects. The Slovakia government suggested for five days, and France government for 10 days quarantine. Most of the countries have suggested a common thing is clean the active surface frequently till the disinfection takes place. 
The Czech government has suggested of ensuring that library staff should wear gloves and masks while handling recently returned library volumes. The Italian Library Association, has suggested, users could be asked to a question whether the materials being returned have been in contact with any infected person?

The Dutch libraries authorities have recommended to reduce the risk, no need to return the books till the situation return to the normal but the limited users should allowed in the library with their paper and pens and that stationary items should not leave in the library.

A real problem looks in the reopening of the libraries is returning of books issued to the users. Various ways have suggested by various agencies. Some of the countries have suggests to return though the RFID based self-circulation system so that without human contact the book returning function could be completed. Some of the authorities have suggested to put a basket around the library so that people will drop the borrowed book in the basket. Some of the agencies have suggested to put the desks so that the borrowers will use them to put the borrowed books. It has been observed that, in Geneva some of the schools have leaving baskets in the classrooms to put the books which will be return after quarantine period. According Polish government guidance the library books returns should be made onto surfaces which can be easily cleaned and disinfect, or on sheets of paper so that it can be disposed of. The Croatian National Library and University Libraries have adopted the basket system, they put some baskets at one entrance used to drop the books due to return, whereas the Japanese Library Association has suggested to use the tables for this purpose. The Australian Library Association recommends using hand gloves for newly returned books and handling them and further suggesting that the hand gloves should be use and through. Whereas some countries have suggesting that the hands gloves quality can't be assured so instead regular hand washing with soap and water works batter for safety purpose.

\section{Storage problem of returned books}

It has been see from the suggestions from various countries the duration of the quarantine of books varies from 2 days to 10 days. Once the books returned which are pending from the day of lockdown, to put them required safe place in the library. The logistical problem may be major problem for the smaller libraries. Many countries have suggested various methods to store the returned books but in Indian situation the libraries should be prepared themselves which will be better option for them. Some alternatives are:

Reserve the specific part of the library for store the returned books, arrange them as date of return and in the same manner remove the books after quarantine period and shift to the stack room. The library can be use external storage if required. Provide access to few staff member in such store room. Ensure that the PPE should be provided to such staff member. Even one can think of portable storage solutions as adopted in America.
The Chinese use centralised book return station, isolate and sterilise them and sending to disinfection section with the help of ultraviolet and ozone disinfection equipment. The USA advised the time itself is the best solution for disinfection for returned books.

\section{Access of books in the library}

The following option have suggested by different countries: No any user should accessible the library books as the Netherlands followed, only librarians themselves should serve this type of service (as in Slovenia and Portugal) (IFLA, 2020). Some libraries have suggested to use of self-service machines to avoid human interaction.

The light reading magazines and daily newspapers, may need to remain inaccessible for the users until the risk is low enough, or it should be accessible only to the people coming with hand gloves and masks as followed in some Estonian libraries.

A further question remained how much and which items should bring the library users along with them?

\section{The Belongings}

There should be restrictions to the users, they should bring their own pen and course material for small preparation, and they should not to leave those items in the library (Dutch guidance).

\section{Recommended isolation period for library material and its arrangement}

The recommended quarantine or isolation period for physical material such as books, DVDs etc. at high of contamination from the COVID-19 virus is between ranges of 24 hours to 72 hours. For the above note period, the returned materials should be placed in boxes, seal them and write a date and time on the boxes and store in an independent location as especially assigned for the purpose.

- Library materials within the library which have not been handled since the lockdown since $23^{\text {rd }}$ March 2020 or since closure of the library are ready for lending as the 72 hours quarantine period has now passed.

- Library materials that were returned before the closure of libraries or before date of the lockdown $23^{\text {rd }}$ March, 2020 (whichever is applicable) and have not been handled, are ready for lending as the 72 hours quarantine period has now passed since the items return.

- Material may be at high risk of contamination when returned to the library at any point after the re-opening and up to 72 hours, if they have been handled by librarians or the library staff following this date, staff should see carefully:

- Date and time of the of return items

- Date and time of last handled the item

- An additional space should be arrange to quarantine of returned books, that may be arranged with removing the furniture available in the library, because to control of the number that should be done till the returning to the original situation. 
Another option may be suggested as external storage area or temporary storage arrangement whichever is possible.

If the library staff can confirm that an item has been isolated (i.e. quarantined or not handled) for complete duration of the quarantine or more, then it can be considered for use in any delivery service or for the putting back to the stack room of the library which may be feasible.

\section{Computer equipment}

Generally the computers and the peripherals are the products of plastics and metals and surface of such equipment has accepted to carry a higher risk. Most of the guidelines prepared for prevention and slowdown of coronavirus have focused on disinfecting the computers, laptops and such devices. The access to computers is seen as essential task for searching, retrieving, copying, and studying purposes. So for safely purpose, it has been suggested in COVID 19 pandemic period that the users should use their own laptop and common computers used for students and others should made inaccessible. The library rules should be revised for the safety of all. The Danish government is totally against to give the library computers to public. Alternative arrangement is that keyboards, the mice and (for extra precautions) the CPUs should be disinfected once it has used by the public.

From the library user's point of view they should be made aware of risk as library staff. Ultimately, either at home or in the library they are supposed to handle the book. Once the user borrowed the book from the library in fact he or she should leave a book for a few days ideal before using it. The duration of say for example 24 hours, the borrowing period should be extended from the library for the sake of safety, and the privilege of extension of duration should know by the users, so that the user can use it properly. Another aspect is to be taking into consideration that, to limit the number of people in the library at a time. This is required to maintain the defined social distance in the library and surrounding area. Pre-booking physical access is also one of the better options to control the number of library users coming to the library at one particular time.

The library should be considered the group of vulnerable people while serving them from the library. The group includes aged and ill people, in the other countries like China, library corners have almost reserved for the vulnerable group so that no one should come in their contact. Here one more point needed to be mention that a group of aged people are most experienced and knowledgeable and they are the asset of the society. Once they came in the contact with the library either personally or through library books it is responsibility of the library to protect them on priority. The libraries which are not yet open, they should have make it clear that what type of safety precaution has been taken while serving to the vulnerable groups and others?

\section{Staff safety}

The basic hygiene measures like washing hands with water and soap, avoiding touching the face, using facemasks and hands gloves, taking precaution while coughing and sneezing. To perform work from home, attend once / twice in a week in office to remain touch to the work place.

\section{Maintain Social Distancing to Delivery library Services}

The close physical contact is the major cause of catching the coronal virus, and only way to avoid the virus is 'social distancing' - keeping a safe distance between two persons in order to reduce the risks of COVID 19 from one person to another. The recommended distance differ from country to country but appears not to be below 1 meter i.e. about 3-4 feet, and more than that may be better.

Most of the libraries in the World have promoted their digital \& online resources access through remote access - for example, Institutional repositories, e-theses and dissertations, leading publishers' databases, e-books, research articles etc. and it should be continued. As a part of the policy matter, there should be provision to increase the ebooks and e-journals, subject collection in the library. The digitization activities should be taken on priority. The remote access facticity should be expanded intensively as well as extensively.

Selected examples of reopening of the libraries from other countries:

The National Library of Serbia (public library) is in the process of reopening the library first time after lockdown. They allowed only five people into its reading room. It has observed in some school libraries of Geneva, allowed just one student at a time.

The National Library of Croatia has made available app to the members to see the vacant place if available in the study room. They allow 200 persons at a time and that is also on the availability of the place. The Russian State Library has set a limit of 100-150 people in the library at one time on the condition of the pre-appointment after re-opening the library. The Dutch government has suggested only two people may allowed in the library at any one time. 'Booking of library visit in advance' is normal activity in some countries after reopening the library. Some of the countries have started some selected services like, scanning, printing and other such services only after pre-appointment. The National Library of China, German National Library and West Virginia have followed the above method of the library services.

\section{Calculation of library users to provide access}

Calculating the right number to be given access to any one time is a key issue of library reopening. We can see the market are around us, they have chalk marked a squares of circles in front shops, banks, food grain powder making grinding mill etc. It can be observed that the distance between the two circles or squares kept around one meter. The virus protective equipment is an essential to everyone when they are coming out from home. The library also need to follow the similar steps for the protection of all. If the building design permit entrance and exit should be provided independently so that no one should brake the rule of maintaining the minimum distance of social distancing between two persons in or around the library. The simple 
method of calculating people (at any) one time in the library is, take a note of the open space area (excluding stack room) say for example $500 \mathrm{Sq}$. Mt. as per the same distance followed by other countries, allocated $20 \mathrm{Sq}$. Mt. in Ireland, Slovenia and Portugal. In Slovakia, Poland and Belgium libraries allocated $15 \mathrm{Sq}$. Mt. per person. In Austria and Czech Republic 10 Sq. Mt. per adult and 5 Sq. Mt. has allocated per child in the library. The Netherlands libraries provide 15 persons per $100 \mathrm{Sq}$. Mt. and while allocating calculating the people in the library the library staff members should be included. In Indian libraries the similar calculation may be advisable and as per the availability of the space and also based on the intensity or level of the virus.

\section{Limit entry of users}

Once the library has given number of person's access the library (maximum) at any time the further problem arise how much time a person can spend in the library? Limiting the time of the accessed persons is very important factor to distribute the library services to the maximum persons. The seating arrangement of the library should be change, only limited seats should be made available, i.e. one person per table and rest of the chairs should be removed from the library till the situation turn to the original position. That will be maintain the social distancing by default in the library. The total time slot to be given to every accessed person will be 30 minutes in a day for pre-booked and permitted person.

As a precautionary measure, the work from home should be promoted and as per the levels of the library. For libraries categorised as level first, 'more or less as usual' (States / UTs where $<99$ active cases found) $50 \%$ staff may be allowed to work in the library. The second level libraries, 'few restrictions' (States / UTs where > 100 and < 999 active cases found) where $25 \%$ library staff may be permitted to attend the library. The third level libraries, 'Minimum service' (States / UTs where $>1000$ and $<5000$ active cases found) less than $25 \%$ library staff may be allowed to attend in the library. The fourth level library, 'Complete close' (Sates / UTs where > 5000 active cases have found) no one should attend the library.

(Note: The categories and number of staff has categorised by the author for the preparation of the library. The librarians can change as per their convenient and situation)

Any service should be delivered in accordance with the following guidelines:

Preparation of physical material for distribution

- Physical material identified for distribution must meet the 72-hour quarantine period whether selected from stack within the library or returned from loan.

- Care should be taken in the handling of physical items for distribution. These should be packaged carefully, securely in a dedicated (reserved area) area in the library.

- Deliveries for each individual member of the public should be packaged separately and securely to avoid risk of cross-contamination.

- Appropriate physical distancing (at least two metres distance between people) must be maintained in the preparation for delivery of physical material at any place, on the way or at the residence of the member or in the library.

\section{Return of physical material}

- Any physical items returned since the closure of libraries on March 23rd (e.g. by book drop or as part of the delivery service) are subject to a 72 hours quarantine. Items should be placed in a separate area if possible in boxes sealed with date marked on the day and time they are returned for the 72 hours quarantine period. After moving materials, hands should be washed with soap and water.

Few examples of reopened libraries in the World:

1. Three public libraries have opened in Australia on $18^{\text {th }}$ of May at Dickinson, Woden and Gungahlin. The working hours they followed as 10.00 am to $5.30 \mathrm{pm}$ and allowed one person per $4 \mathrm{Sq}$. Mt. for maximum 30 minutes on pre-booking (ALIA, 2020).

2. The public libraries of New South Wales have reopened from $1^{\text {st }}$ June 2020. They have put the restriction on number of persons in the library at any one time in such a way that the staff, the volunteers and visitors should not exceed one person per 4 Sq. Mt. area. They also followed 24 hours quarantine period for returned collection (SLNSW, 2020).

3. Northern Territory Government roadmap: All the public libraries of Northern Territory Government have reopened from $21^{\text {st }}$ May. The maximum number of persons in the library at any one time has set that more than 10 people are not allowed. The ratio of the area to person has observed as $1.5 \mathrm{Sq}$. Mt. per person, and the timing of maximum two hours has given. (Northern Territory Government, 2020).

4. Libraries of Queensland have started reopening from $15^{\text {th }}$ May. Ten people are allowed in the library at any one time. They have strictly following the norm of social distancing as well as hygiene measures.

5. The Libraries of South Australia have started reopening from $11^{\text {th }}$ of May. Maximum ten patrons are allowed in the library but further taking care of not exceeding one person per $4 \mathrm{Sq}$. Mt. at any one time. The social distancing norms are followed strictly and beverages and food items are restricted in the library.

6. The few libraries of Tasmania have started from $18^{\text {th }}$ May. The process of planning of reopening the libraries has initiated but the libraries are not allowed for public for browsing and visiting (Gutwein, 2020).

Some of the world level examples have listed to follow the suitable method/s in Indian situation when the libraries reopened.

Last but not least, it may also be worth ensuring that libraries must have a plan for how to deal with situations where someone displays symptoms, for example by having COVID 19 relevant helpline contact numbers, (if available) name of the medical advisor, setting aside a room where it is possible to isolate a suspected victim. 


\section{Conclusion}

Most of the libraries in India have closed down with assumption that the COVID 19 pandemic chain will break and slow down or come under control. But day by day the numbers of active cases and the deaths are increasing. Further every Indian State and Union Territory has different scenario. The Government is in the process of reopening the educational institutions in near future, ultimately the libraries have also required to re-open with well-prepared strategies. The unique strategy, will not useful for the vast country like India where the intensity of the pandemic varies from place to place. Hence the author has suggested different strategies, methods of operation into four different levels based on the number of COVID 19 cases. He has introduced with meaning and spread of COVID 19 pandemic. In brief he has stated World level scenario of different types of libraries. Indian situation of COVID 19 at state level and accordingly how different type of libraries would take different steps to slow down and to control the pandemic. He extended his views with how to protect the clienteles, the staff and the library resources in different types of situations.

\section{Source of Funding}

None.

\section{Conflict of Interest}

None.

\section{References}

1. Van Doremalen, Neelatje et al., (2020): Aerosol and Surface Stability of SARS-CoV-2 as Compared with SARS-CoV-1. New England Journal of Medicine, 17 March 2020, (correspondence).

2. https://www.nejm.org/doi/full/10.1056/NEJMc2004973, DOI: 10.1056/NEJMc2004973

3. UNICEF et al. (2020): Key messages and actions for COVID 19: prevention and control in schools $2 \mathrm{p}$. https://www.who.int/docs/default-source/coronaviruse/keymessages-and-actions-for-covid-19-prevention-and-control-inschools-march-2020.pdf?sfvrsn=baf81d52_4
4. World Health Organization (2020): Coronavirus disease (COVID-19) technical guidance: Humanitarian operations, camps, and other fragile settings as well as refugees and migrants in non-humanitarian and non-camp settings, https://www.who.int/emergencies/diseases/novel-coronavirus2019/technical-guidance

5. International Federation of Library Association (2020): COVID 19 and the global library field. https://www.ifla.org/covid-19-and-libraries\#closures

6. Government of India, Ministry of Health \& Family Welfare (2020): COVID in India as on $7^{\text {th }}$ June 2020

www.mohfw.gov.in

7. International Federation of Library Association (2020): Op. Cit.

8. Van Doremalen, Neelatje et al., (2020): Op. Cit.

9. IFLA (2020): Op. Cit.

10. IFLA (2002): ibid

11. Australian Library Association (2020): Australian Government Responding to COVID 19. https://www.alia.org.au/australianlibraries-responding-covid-19

12. State Libraries New South Wales (2002): COVID 19, information for public libraries. https://www.sl.nsw.gov.au/public-library-services/covid-19

13. Government of Northern Territory (2020): Road map to the new normal. https://coronavirus.nt.gov.au/roadmap-newnormal

14. Government of South Australia (2020): Local Government Libraries: Road map to reopen the libraries: COVID 19 South Australia Factsheet. https://www.covid19.sa.gov.au/_data/assets/pdf_file/0003/196635/

15. Gutwein, Peter (2002): Our plan to rebuilt stronger Tasmania https://issuu.com/petergutweinmp/docs/our_plan_to_rebuild_a _stronger_tasmania

16. Victoria, State Government (Department of Health Service) (2002): Community

17. Service. https://www.dhhs.vic.gov.au/community-servicesrestrictions-covid-19\#are-public-libraries-open

How to cite: Mestri DD, Reopening libraries in COVID 19 pandemic: challenges and recommendations. IP Indian $J$ Libr Sci Inf Techno 2020;5(1):16-23. 